\title{
Recovery and Use of Blast Furnace Slag in the Field of Road Construction in Algeria
}

\author{
Kamel Rouabah, Abdesselam Zergua, Ahmed Beroual, Mohamed Nacer Guetteche \\ Department of Civil Engineering, Constantine 1 University, Constantine, Algeria \\ Email: mnguetteche@yahoo.fr
}

Received January 16, 2012; revised April 5, 2013; accepted April 13, 2013

Copyright (C) 2013 Kamel Rouabah et al. This is an open access article distributed under the Creative Commons Attribution License, which permits unrestricted use, distribution, and reproduction in any medium, provided the original work is properly cited.

\begin{abstract}
Waste and industrial by-products represent a significant percentage of the industrial landfill. The evaluation of these products has a dual effect: it avoids both the landfill (risk of environmental pollution) and limits the use of natural aggregates (depletion of natural resources and landscape fragmentation and the imbalance of the ecosystem). In recent years, applications for industrial waste have been taken into account in the construction of roads with a great interest in many industrialized countries and developing countries. The use of these materials in the construction of the road is a decision based on technical, economic and ecological criteria. In Algeria, the steel plant of El-Hadjar (Annaba), due to its activity generates a significant industrial waste (slag) which creates a storage problem and pollution. For industrialized countries, this product is an abundant raw material at low cost that must be used on a large scale public works. Our study implies the use of slag in the preparation of the subgrade and surface course (as coated). The results of chemical, physical and mechanical analyses of El-Hadjar slag and materials developed, compared to those of natural aggregates, can be used as aggregate in road construction.
\end{abstract}

Keywords: Bitumen Road; Platform; Mechanical Testing; Blast Furnace Slag

\section{Introduction}

Nowadays, the elimination of various waste products from different industries is a serious problem. These materials have an environmental pollution in the nearby community in recent years; applications of industrial wastes have been taken into account in road construction with a great interest in many industrialized and developing countries [1]. The use of these materials in the construction of roads is a decision based on technical, economical and ecological criteria [2-5].

To preserve the environment, natural resources, encourage recycling, we base our present study on the development of blast-furnace slag in the road. Construction and road maintenance require huge amounts of aggregates, rather restrictive specification road that only certain categories of materials are commonly used $[6,7]$.

These industrial wastes represent a significant percentage of the industrial landfill. The valuation of these products has a twofold effect: it avoids the landfill (risk of environmental pollution) and limits the use of natural aggregates (natural resource depletion and fragmentation of the landscape ecosystem).

The recovery of blast furnaces slag is not currently subjected to national rules regarding the use and protection of the environment. Moreover, the public works management is conducting a national action plan to encourage research in this direction [8]. This stems partly from the long experience in the use of these slags in road work, and using that to date has not revealed any adverse impact on the ecological system [9].

Slag is a by-product of iron making in blast furnace steel mills. For a cubic meter of molten metal 280 to 340 $\mathrm{kg}$ of milk is produced in modern blast furnaces. In Algeria the annual production of milk is estimated at 500,000 tones finding only a few applications $[10,11]$. In cement, granulated slag is only used as additions to Portland cement, obtained by rapid cooling to keep the glassy state. Cons by crystallized slag is obtained by slow cooling in air, gives a rock hard, angular, after crushing and screening, can be used as aggregate in concrete pavement foundation materials, embankment, asphalt [12]. So the metal industry-steel is the largest producer of waste that often has a negative image and poses a disposal problem and nuisance to the environment.

The concern of industry is to get rid of the waste or use them in new forms in the materials of construction 
industry and thus find a new life and save natural resources and protect the environment.

This study is an attempt to use the blast furnace slag in road construction or in the sub grade or in the wearing course (the coats). The study involves the use in the subgrade of natural materials and careers available in the vicinity of the site, the slag is introduced with a percentage and the result of successive Proctor determining the optimal percentage of dairy used. For asphalt mixture used in proportions, aggregate and binder to wait for better mechanical characteristics is selected by introducing a percentage of slag in the formulation, while retaining single type of bitumen for the first time.

\section{Subgrad}

To construct the sub-grad, natural materials and of career available in the vicinity of the building site are used. The slag is introduced with a successive percentage. The results of Proctor tests give the optimal percentage of the used slag [13].

\subsection{Materials}

The used materials in the present study are: a crushed material from the career SOREST, located at Ouedi Sagan (Mila) in eastern Algeria; a roller material fras; artificial materials as the granulated slag and crystallized slag, coming from the iron and steel plant of El-Hadjar (Annaba) in eastern Algeria and a ground of the type (tuff-limestone).

\subsection{Deduction and Sampling}

The tests have been carried out at the Materials Laboratory of Civil Engineering at Constantine University. Sampling carried out on heaps for the case of granular materials, or on site for tuff while complying with the regulations relating to the deduction and sampling [14].

\subsection{Classification Tests}

Chemical composition of the slag, depends on the iron bearing load of the blast furnace and is adjusted in order to allow the elimination of the harmful elements to the working of the blast furnace and the quality of the cast iron [15] (Tables $\mathbf{1}$ and 2).

The values of the index of alkalinity of both slags are of 1.12. It means that they are of basic nature. Table 3 shows the initial water content and the density of various materials.

It is noted that the water content is high in the case of granulated slag. This is due to its heat balance which takes into account the variation of enthalpy, when the slag passes from $1450^{\circ} \mathrm{C}$ to $100^{\circ} \mathrm{C}$. About 600 litres of water is needed to ensure its cooling and its dispersion.
Table 1. Chemical composition of the crystallized slag.

\begin{tabular}{cc}
\hline Chemical composition & Content in \% \\
\hline $\mathrm{CAD}$ & 41.6 \\
$\mathrm{AlO}_{3}$ & 5.1 \\
$\mathrm{FeO}_{3}$ & 0.35 \\
$\mathrm{SiO}_{2}$ & 40.33 \\
$\mathrm{KO}$ & 0.29 \\
$\mathrm{NaO}$ & 0.07 \\
$\mathrm{TiO}_{2}$ & 0.21 \\
$\mathrm{PO}_{5}$ & 0.05 \\
$\mathrm{IP}=$ & $\mathrm{CaO}_{\mathrm{SiO}_{2}}$ \\
\end{tabular}

Table 2. Chemical composition of the granulated slag.

\begin{tabular}{|c|c|}
\hline Chemical composition & Content in \% \\
\hline $\mathrm{CAD}$ & 39.55 \\
\hline $\mathrm{AlO}_{3}$ & 7.40 \\
\hline $\mathrm{MgO}$ & 4.33 \\
\hline $\mathrm{FeO}_{3}$ & 1.51 \\
\hline $\mathrm{SiO}_{2}$ & 37.82 \\
\hline $\mathrm{MnO}$ & 2.09 \\
\hline $\mathrm{KO}$ & 0.23 \\
\hline $\mathrm{NaO}$ & 0.09 \\
\hline $\mathrm{TiO}_{2}$ & 0.19 \\
\hline $\mathrm{PO}_{5}$ & 0.11 \\
\hline $\mathrm{IP}=\mathrm{CaO} / \mathrm{SiO}_{2}$ & 1.04 \\
\hline
\end{tabular}

Table 3. Initial water content and densities of materials.

\begin{tabular}{cccc}
\hline Materials & $\begin{array}{c}\text { Water content } \\
(\%)\end{array}$ & $\begin{array}{c}\text { Apparent } \\
\text { density }\left(\mathrm{t} / \mathrm{m}^{3}\right)\end{array}$ & $\begin{array}{c}\text { Absolute } \\
\text { density }\left(\mathrm{t} / \mathrm{m}^{3}\right)\end{array}$ \\
\hline Granulated slag & 10.5 & 1.08 & 2.83 \\
Crystallized slag & 1.05 & 1.4 & 2.67 \\
Tuff-limestone & 4.10 & 1.82 & 2.10 \\
All come limestone & 1.4 & 1.39 & 2.65 \\
All come natural & 0.5 & 1.50 & 2.85 \\
\hline
\end{tabular}

\subsection{Mechanical Tests}

The parameters of mechanical behaviour are considered with an aim of distinguishing the materials whose granular fraction is likely to resist the traffic of those which are likely to split up. Table 4 shows different mechanical properties of various materials.

It is noted that the granulated slag has a water natural content $(W n=10.2 \%)$ and optimum water $(W o p=$ $14.6 \%)$. However, the crystallized slag presents $(W n=$ $0.6 \%$ and $W o p=2.5 \%$ ), which does not need a great quantity of water for their compaction.

Table 5 shows the optimum water and optimum density couples for various materials, obtained from Proctor 
Table 4. Mechanical parameters of various materials.

\begin{tabular}{ccccc}
\hline \multirow{2}{*}{ Materials } & \multicolumn{4}{c}{ Tests of Mechanical Behavior } \\
\cline { 2 - 5 } & FS & $\begin{array}{c}\text { Los } \\
\text { Angeles }\end{array}$ & $\begin{array}{c}\text { Dynamic Frag } \\
\text { Mentation }\end{array}$ & $\begin{array}{c}\text { Micro Deval } \\
\text { Damp }\end{array}$ \\
\hline Granulated slag & $15.20 \%$ & - & - & - \\
Crystallized slag & - & $24 \%$ & $22 \%$ & $26.8 \%$ \\
Tuff-limestone & - & - & - & - \\
All come-limestone & - & $25 \%$ & $22 \%$ & $23 \%$ \\
All come-natural & - & $15 \%$ & $14 \%$ & $21 \%$ \\
\hline
\end{tabular}

Table 5. Optimum water and optimum density according to proctor test.

\begin{tabular}{ccc}
\hline Materials & Optimum Water (\%) & Optimum Density $\left(\mathrm{g} / \mathrm{cm}^{3}\right)$ \\
\hline Granulated slag & $14.6 \%$ & 1.26 \\
Crystallized slag & $2.5 \%$ & 1.75 \\
Tuff-limestone & $13.6 \%$ & 1.85 \\
All come limestone & $6.0 \%$ & 2.16 \\
All come-natural & $13.1 \%$ & 1.85 \\
\hline
\end{tabular}

tests [13-16].

We observe that the slag density presents a considerable variation compared with the density of Proctor optimum. This reflects the sensitivity of material to the compaction operation.

\subsection{Correction of the Slag}

With an aim of improving the mechanical characteristics of the slag, a slag mixture-tuff with various percentages have been formulated. Table 6 shows the different mixtures.

Table 7 shows the Proctor test results.

In the case of a correction with the tuff, a light increase in the water content optimal is observed. The latter to be decreased so much according to the percentage of addition. With regard to the density, an apparent increase in correction with $30 \%$ of tuff makes increase the density of $30 \%$. In the case of a correction with the crystallized slag, the results show a reduction in the Proctor optimum accompanied by an increase of density of about $35 \%$. For the mixer tuff-limestone, the best density is given by the mixture $\mathrm{D}$.

\section{Wearing Course}

The wearing course (binder bitumen) is the surface part of the pavement. It has two functions. On one hand, it ensures the protection of the under lays with respect to the water infiltrations. And on the other hand, it brings comfort for users witch respect to the good characteristics of surface [13].
Table 6. Formulation of the mixtures.

\begin{tabular}{cccc}
\hline Mixture & Granulated slag & Tuff-limestone & Crystallized slag \\
\hline A & $100 \%$ & $0 \%$ & - \\
B & $90 \%$ & $10 \%$ & - \\
C & $80 \%$ & $20 \%$ & - \\
D & $70 \%$ & $30 \%$ & - \\
E & $0 \%$ & $100 \%$ & - \\
F & $50 \%$ & - & $50 \%$ \\
\hline
\end{tabular}

Table 7. Optimum water and optimum density according to proctor test for the mixtures.

\begin{tabular}{ccc}
\hline Mixture & W opt (\%) & Density opt $\left(\mathrm{t} / \mathrm{m}^{3}\right)$ \\
\hline A & 14.6 & 1.26 \\
B & 16.1 & 1.38 \\
C & 15.9 & 1.46 \\
D & 15.1 & 1.55 \\
E & 13.6 & 1.85 \\
F & 11.8 & 1.67 \\
\hline
\end{tabular}

\subsection{Classification Tests of Materials}

The aggregates are distributed according to their average size in several families: fines, sands, fine gravels and stones. The minimal and maximum diameters of these families are standardized.

The granularity is the dimensional distribution of the grains of an aggregate. It conditions the compactness of the bituminous mixture and its mechanical characteristics.

To constitute the granular skeleton of the bituminous mix, the various size ranges in a certain proportion have been mixed.

The distribution of the various grains size (for large to small) constitutes the grading curve of the mixture. It can be continuous or discontinuous (i.e. that one or more granular fractions can miss), according to the destination of the mixture and the properties concerned. For draining example the grading curve of the bituminous mix is strongly discontinuous. This makes it possible to obtain a raising porosity raised after the installation [17]. The used aggregates come from the careers of crushing of the area of Constantine.

The bitumens are composed of carbon and hydrogen. They are used in industry for its properties of sealing and isolating (thermal and acoustic). Nevertheless, the road applications are important because $90 \%$ of bitumen production is used in the form of bituminous mix and surface dressings. In addition, it is estimated that the totality of the rough world's oil reserves should exceed the 600 WP, which lets predict a lengthy and good future with 
this industry [18].

The bitumen used is class 40/50 [19]. Pure bitumen is obtained by the vacuum packed of oil followed by a blowing to the air; its characteristics are presented in Table 8.

\subsection{Mechanical Tests on the Aggregates}

The results of the tests carried out are gathered in Tables $\mathbf{9}$ and $\mathbf{1 0}$.

\subsection{Formulation of the Bitumen Binders}

The bitumen binder inherits the viscoelastic characteristics of the binder which it contains. Its mechanical properties depend on the duration of solicitations (or its frequency) and on the temperature. They are included in the category of viscoelastic and thermoplastic materials [20].

In the literature, the bituminous materials are generally regarded as being homogeneous, isotropic, viscoelastic, linear and thermo likely.

The formulation of a bituminous mix must fulfil the requirements of the standards and ensure certain parameters as the handiness, which is a primordial characteristic since it facilitates obtaining a good plain of roadway; resistance to the rutting, because the absence of rut on the roads increases the safety of the users; resistance to thermal cracking and by fatigue of the bituminous mix.

The proportion of the adopted mixtures is as follows (proportion used by several companies in Algeria): $38 \%$ of aggregates; $20 \%$ ofgravels and $42 \%$ sand.

To analyze the influence of the slag on the mechanical and rheological behaviour of the bituminous mix, successive proportions of slag have been constituted by a step of $5 \%$ of the whole of the test-tubes. For each formulation, the curve of the mixture has been verified by the specific spindle of the BB $0 / 14$.

Initially a fraction of gravels is used. Then the percentage of the slag varies from $0 \%$ (pilot test) until the totality of gravels will be in slag, which corresponds to $20 \%$.

The principal objective is to find an optimal value of the slag to be injected in order to have bituminous mix with better qualities.

During the tests, the aggregates of career 2 (aggregates of better mechanical characteristics) have been selected.

Duriez stability results for different slag contents are presented in Figure 1.

It is clear from Figure 1 that Duriez stability decreases progressively with the increase of the slag contents in the mixture. By comparing these results with stability limits required by the code is about $35 \mathrm{KN}$ (70 bars) for an asphaltic concrete $\mathrm{BB} 0 / 14$ with a bitumen $40 / 50$. It is not possible to exceed the value of $13 \%$ of slag which
Table 8. Characteristics of bitumen.

\begin{tabular}{ccccc}
\hline $\begin{array}{c}\text { Penetration } \\
\text { at 25 C }\end{array}$ & $\begin{array}{c}\text { Not softening } \\
\text { and ring }\end{array}$ & $\begin{array}{c}\text { Density relating } \\
\text { to } 25 \mathrm{C}\end{array}$ & $\begin{array}{c}\text { Not } \\
\text { flamme } \mathrm{C} \text { during } 5 \text { hours }\end{array}$ & $\begin{array}{c}\text { Loss of heat } 163 \\
\text { flaris }\end{array}$ \\
\hline 46 & 57 & 1.05 & 264 & $<1 \%$ \\
\hline
\end{tabular}

Table 9. Results of Los Angeles test.

\begin{tabular}{ccccc}
\hline $\begin{array}{c}\text { Aggregate } \\
\text { source }\end{array}$ & $\begin{array}{c}\text { Los } \\
\text { Angeles \% }\end{array}$ & $\begin{array}{c}\text { Dynamic } \\
\text { frgmentation } \%\end{array}$ & $\begin{array}{c}\text { Size range } \\
\text { for the test }\end{array}$ & specification \\
\hline Career 1 & 24 & 28 & $4-6.3$ & $\leq 25$ \\
Career 2 & 22.4 & 23 & $4-6.3$ & $\leq 25$ \\
Career 3 & 23 & 25 & $4-6.3$ & $\leq 25$ \\
Crystallized slag & 24 & 22 & $4-6.3$ & $\leq 25$ \\
\hline
\end{tabular}

Table 10. Results of Micro-Deval test.

\begin{tabular}{ccccc}
\hline $\begin{array}{c}\text { Aggregate } \\
\text { source }\end{array}$ & $\begin{array}{c}\text { Microphone } \\
\text { dry Deval } \\
\text { MDS \% }\end{array}$ & $\begin{array}{c}\text { Wet microphone Size range } \\
\text { Deval MDE \% for the test }\end{array}$ & Specification \\
\hline Career 1 & 4.4 & 17 & $4-6.3$ & MDE $\leq 20$ \\
Career 2 & 5 & 20 & $4-6.3$ & MDE $\leq 20$ \\
Career 3 & 5 & 18 & $4-6.3$ & MDE $\leq 20$ \\
Crystallized slag & 4.4 & 20 & $4-6.3$ & MDE $\leq 20$ \\
\hline
\end{tabular}

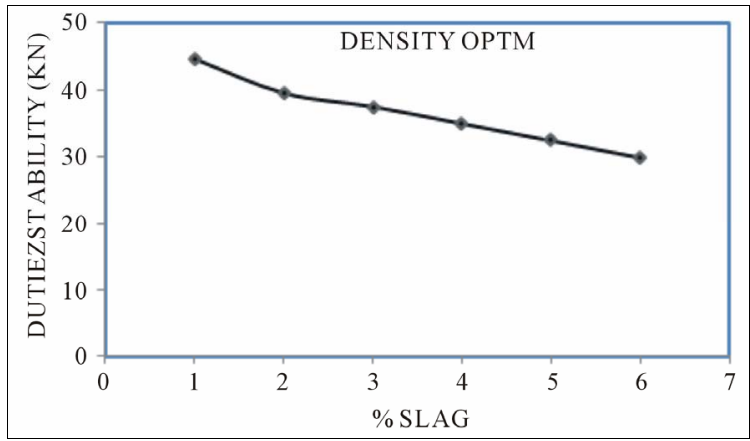

Figure 1. Duriez stability for different slag contents.

gives a stability of 71.6 bars.

It is noted that stability is inversely proportional to the percentage of the vacuum (Figure 2).

It is noted that the slag does not have a significant influence on \% of depression (Figure 3). It behaves like an unspecified aggregate.

The adhesiveness increases according to $\%$ of the slag, this is due to the rough surface of the slag and its affinity with the binder (Figure 4).

Figure 5 shows that stability is obtained even thus the ratio of adhesiveness are increasing.

Figure 6 shows that the index of vacuums of the testtube increases gradually with slag contents, because the slag is a porous material.

\section{Conclusions}

According to the bibliographical study, as well as the 


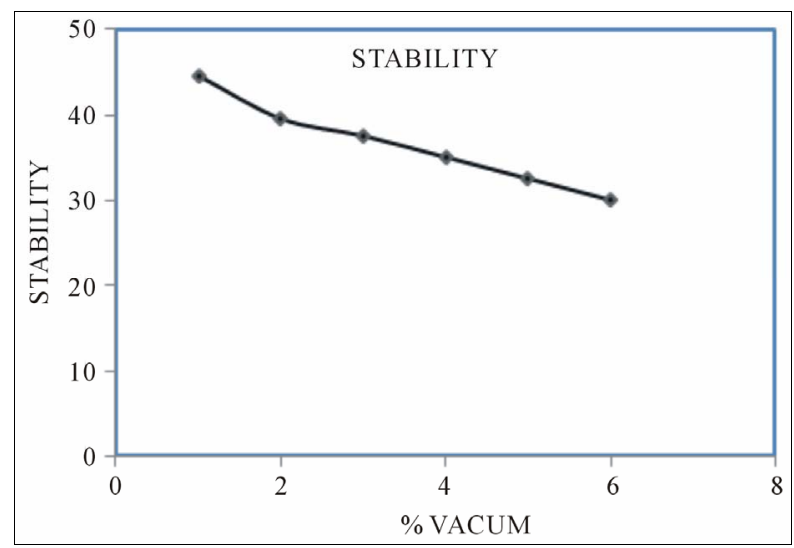

Figure 2. Stability for different vacuum contents.

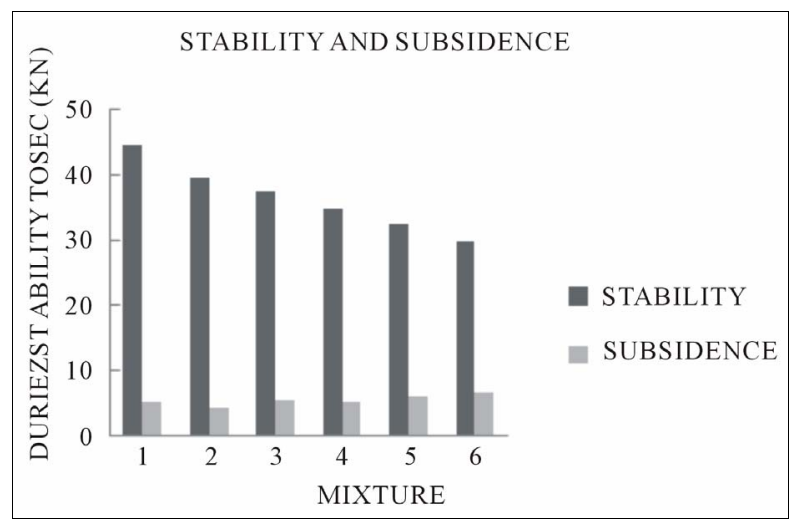

Figure 3. Stability for different vacuum contents.

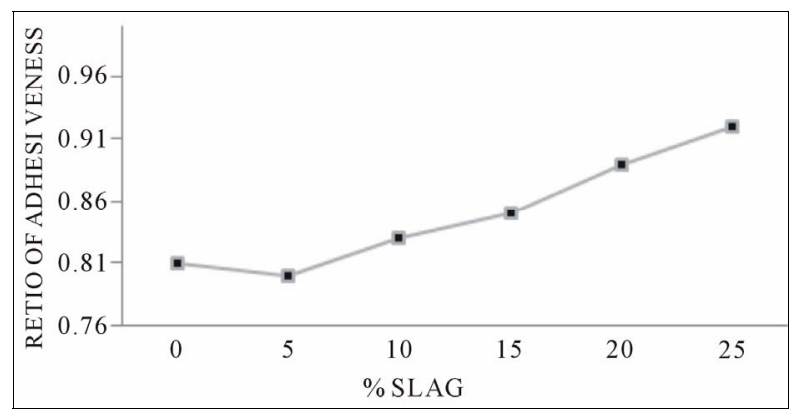

Figure 4. Adhesiveness report/ratio according to \% of the slag.

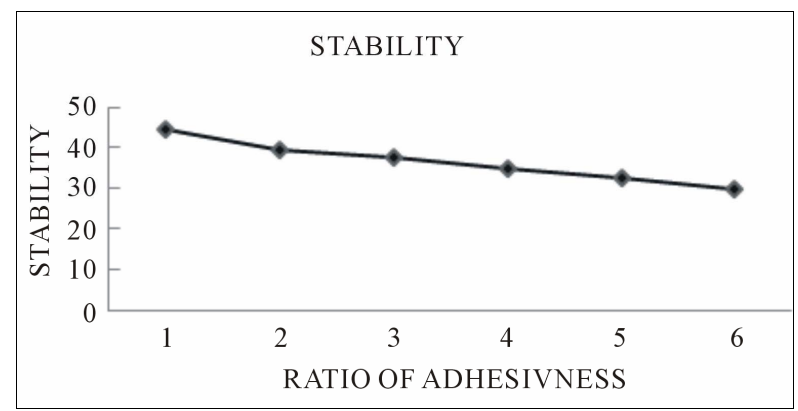

Figure 5. Stability according to the report/ratio of adhesiveness.

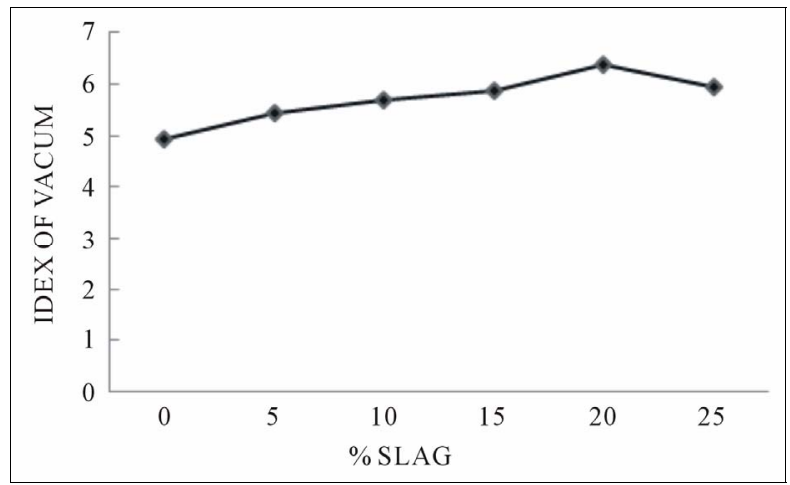

Figure 6. Index of vacuums for different slag contents.

experimental results obtained, the subgrads of the road infrastructures can consume the slags produced or stored with significant quantities.

The slags are placed for such a use, because they are insensitive materials with water, quality essential for a use in sub-grade.

This insensitivity is due primarily to its cleanliness and its small percentage of tamis at lower than $80 \mu \mathrm{m}$.

The granulated slag has a very tight grain-size distribution, which decreases its aptitude for the compaction, and it will be necessary thus to carry out a correction with other material (the tuff in our case), to determine the optimum percentage (30\% for the tuff).

With the instar of the industrialized countries, the use of the blast furnaces slag of El-Hadjar in the construction of roads is an economic stake for Algeria and a solution of this by-product as the pollution, the storage...

\section{REFERENCES}

[1] T. Sen and U. Mishra, "Usage of Industrial Waste Products in Village Road Construction," International Journal of Environmental Science and Development, Vol. 1, No. 2, 2010, pp. 122-126.

[2] M. A. Elgharbi and R. Znaidi, "Valorisation des Scories d'Acierie Eléctrique Pour l'Entretien des Routes Rurales," Revue HTE, Vol. 7, No.134, 2006, pp. 45-50.

[3] P. Chaurand, J. Rose, V. Briois, L. Olivi, J.-L. Hazemann, O. Proux, J. Domas and J.-Y. Bottero, "Environmental Impacts of Steel Slag Reused in Road Construction: A Crystallographic and Molecular (XANES)," Journal of Hazardous Materials, Vol. 139, No. 3, 2007, pp. 537-542. doi:10.1016/j.jhazmat.2006.02.060

[4] W. Shena, M. Zhoua, W. Mab, J. Hub and Z. Caib, "Investigation on the Application of Steel Slag-Fly AshPhosphogypsum Solidified Material as Road Base Material," Journal of Hazardous Materials, Vol. 173, No. 1, 2010, pp. 468-473.

[5] D. Durincka, F. Engströmb, S. Arnouta, J. Heulensa, P. T. Jonesa, B. Björkmanb, B. Blanpaina and P. Wollants, "Hot Stage Processing of Metallurgical Slags," Conservation and Recycling, Vol. 52, No. 10, 2008, pp. 1121-1131. 
[6] L. Roth and M. Eklund, "Environmental Evaluation of Reuse of By-Products as Road Construction Materials in Sweden," Waste Management, 2003, pp. 107-116. www.elsevier.com/locate/wasman

[7] D. Qiao, J. S. Qian, Q. Z. Wang, Y. D. Dang, H. Zhang and D. Q. Zeng, "Utilization of Sulfate-Rich Solid Wastes in Rural Road Construction in the "Three Gorges Reservoir for Rural Road Construction," Conservation and Recycling, Vol. 54, No. 12, 2010, pp. 1368-1376.

[8] "Direction de la Recherche et de la Perspective," Ministère des Travaux Publique, Algérie. www.mtp.gov.dz/drp.htm

[9] J. Sorvari, "Developing Environmental Legislation to Promote Recycling of Industrial By-Products-An Endless Story," Waste Management, Vol. 28, No. 3, 2008, pp. 489- 501.

[10] A. Malek, "Caractéristique Physico-Chimique de Haut Fourneau," Séminaire de Génie Civil, Annaba, 2000, pp. 19-23.

[11] H. Rizzi, "Valorisation et Commercialisation des Sous Produits du Complexe Sidérurgique d'El Hadjar," Séminaire de Génie Civil, Annaba, 1998, pp. 26-29.

[12] A. Boudjelli, "Utilisation du Laitier en Technique Routière," Séminaire de Génie Civil, Annaba, 1998, pp. 56-
60.

[13] LCPC, "Conception et Dimensionnement des Structures des Chaussées," Guide Technique, LCPC - SETRA, France, 1994, 266 p.

[14] R. Dupain, “Granulats, Sols, Ciments et Bétons," Edition Casteilla, France, 1995, 235 p.

[15] Fiche Technique de Laboratoire de Bâtiments et Travaux Publics, Algérie, 2007, 20 p

[16] “Catalogue des Structures de Chaussées," France, 2003, $105 \mathrm{p}$.

[17] A. Lachiheb, "Application à la Détermination des Propriétés Elastiques et en Fatigue des Enrobés Bitumineux," Thèse de Doctorat, Ecole Nationale des Travaux Publiques, Algérie, 2004, 160 p.

[18] S. Bitumes, "Bitumes-Techniques et Utilisations," Société des Pétroles Shell, Direction Bitumes, Paris, 1991, $149 \mathrm{p}$.

[19] Entreprise Nationale de Commercialisation et de Distribution des Produits Pétroliers, Sonatrach, Site Officiel de NAFTAL SPA-Algérie. www.naftal.dz/produits.php.

[20] L. Francken, "Module Complexe des Mélanges Bitumineux," Bulletin de Liaison des Laboratoires des Ponts et Chaussées, No. 5, 1977, pp. 181-198. 